\title{
AOS NOSSOS LEITORES E COLABORADORES
}

\section{“CADERNOS DE SAÚDE PÚBLICA" presta contas}

No momento em que lançamos o vol. $2 \mathrm{n}$ ? 1, com algum atraso apesar do grande esforço da Editoração, voltamos a solicitar aos prezados colegas sua valiosa colaboração para os próximos números dos CADERNOS.

A situação atual do nosso periódico é a seguinte:

Vol. 1, 1985, (número 1 a 4) - publicado

Vol. 2, 1986

$$
\begin{aligned}
& \text { no 1, impresso } \\
& \text { (janeiro-março) } \\
& \text { no } 2 \text {, em impressão } \\
& \text { (abril.junho) } \\
& \text { no } 3 \text {, em composição } \\
& \text { (julho-setembro) } \\
& \text { no } 4 \text {, em organização } \\
& \text { (outubro-dezembro) }
\end{aligned}
$$

0 atraso do "CADERNOS" foi devido, exclusivamente, a problemas burocráticos. Com a descentralização do orçamento da ENSP e as modificações da estrutura da

\begin{tabular}{|c|c|c|c|}
\hline Seções & $\begin{array}{c}1 \\
\text { ENSP }\end{array}$ & $\begin{array}{c}2 \\
\text { Outras unid. } \\
\text { FIOCRUZ }\end{array}$ & $\begin{array}{c}3 \\
\text { Outras } \\
\text { Instit. }\end{array}$ \\
\hline
\end{tabular}
FIOCRUZ, esperamos poder contornar os problemas mencionados, colocando em dia o nosso maior veículo de comunicacão.

Durante seu primeiro ano de existência, i. e., nos seus quatro primeiros números, "CADERNOS" mostrou a seguinte distribuição da matéria publicada, por seção e por instituição:

$\begin{array}{lrrrr}\text { Editorial } & 3 & - & 1 & 4 \\ \text { Pesquisa } & 8 & - & 3 & 11 \\ \text { Artigo } & 10 & - & 4 & 14 \\ \text { Debate } & - & - & 2 & 2 \\ \text { Comunic. breves } & 3 & - & 2 & 5 \\ \text { Opinião } & 2 & - & 4 & 6 \\ \text { Análise } & 1 & - & - & 1 \\ \text { Resenha } & 10 & - & - & 10 \\ \text { Tema } & \text { nova seção programada para } & \text { "1986 } & \\ \text { Entrevista } & " & " & " & " \\ \text { Registro } & - & - & - & -\end{array}$

Cadernos de Saúde Pública, R.J., 2 (1): 107-108, jan/mar,1986. 
"CADERNOS" é uma publicação aberta a todos os que colaboram para construção do nosso patrimônio cultural no campo da Saúde Pública. Colabore conosco enviando sua contribuição e/ou suas críticas e sugestões.

Os Editores 